\title{
Effect of 4-(4'-Chlorobenzyloxy)benzyl Nicotinate (KCD-232) on Cho- lesterol Metabolism in Rats Fed an Amino Acid Imbalance Diet
}

\author{
Kazumi Yagasaki, Kodo OKada, Kouichi TaKagi \\ and Tsutomu IRIKURA \\ Kyorin Central Research Laboratories, \\ Nogi-machi, Tochigi 329-01, Japan
}

Received August 23, 1983

\begin{abstract}
The effect of KCD-232, a new hypolipidemic agent with the structure of 4-(4'-chlorobenzyloxy)benzyl nicotinate, on cholesterol $(\mathrm{Ch})$ metabolism was studied in rats fed a methioninesupplemented low casein (with threonine imbalance) diet.

A methionine-supplemented $10 \%$ casein (imbalance) diet caused an increase in serum $\mathrm{Ch}$ when compared to a $10 \%$ casein diet, while the supplement of methionine to a $20 \%$ casein diet caused no further increase. In rats fed the imbalance diet, $\mathrm{KCD}-232$ reduced the serum $\mathrm{Ch}$ level. Measurement of $\mathrm{Ch}$ absorption using a dual-isotope serum ratio method showed neither an enhancement in the imbalance diet-fed rats nor a reduction in the drug-treated, imbalance diet-fed rats. However, radioactivities in the serum of orally given $\left[{ }^{3} \mathrm{H}\right] \mathrm{Ch}$ and intravenously given $\left[{ }^{14} \mathrm{C}\right] \mathrm{Ch}$ increased in the imbalance diet-fed rats and decreased in the KCD-232-treated rats. Hepatic sterol synthesis measured in vivo using $\left[{ }^{3} \mathrm{H}\right]$ water was unchanged in the imbalance diet-fed rats and increased in the drug-treated rats.

These results suggest that the clearance of $\mathrm{Ch}$ from the circulation system, which may be impaired in rats fed the imbalance diet, is enhanced in the KCD-232-treated, imbalance diet-fed rats.
\end{abstract}

It is well known that dietary protein plays an important role in regulating the concentration of serum Ch. ${ }^{1,2)}$ A Ch-free, low fat, semipurified diet containing casein, an animal protein, has been reported to develop equal hypercholesterolemia and athersclerosis to a $\mathrm{Ch}$ supplemented diet in rabbits. ${ }^{3)}$ The endogenous hypercholesterolemia can be enhanced by increasing the proportion of dietary casein in rabbits ${ }^{4)}$ and rats. ${ }^{5)}$ By contrast, soy protein, a vegetable protein, shows hypocholesterolemic properties in rabbits, ${ }^{1,2)}$ humans ${ }^{6)}$ and rats. ${ }^{7)}$ Purified whole egg protein has been reported to induce not only fatty liver but also an increase in serum LDL-Ch in rats fed a low protein diet containing the protein. ${ }^{8)}$ Feeding a diet containing low casein supplemented with cystine is known to develop fatty liver in rats, which is reduced if the diet is supplemented with threonine. ${ }^{9)}$ There seem to exist similarities between the low whole egg protein and the sulfur-containing amino acid-supplemented low casein diets in regard to both the relative content of sulfur-containing amino acids and their effects on lipid metabolism. The specific effects of certain amino acids on serum $\mathrm{Ch}$ have been demonstrated; for instance, high glutamic acid intakes depressed serum $\mathrm{Ch}^{10}$ ) while histidine caused hypercholesterolemia. ${ }^{11)}$ KCD-232, 4-(4'-chlorobenzyloxy)benzyl nicotinate, has been found to be a new hypolipidemic agent without any appreciable toxicity in the study of a series of compounds and has been shown to possess a hypocholesterolemic activity in rats. ${ }^{12)}$ The present work was underteken to study the effect of $\mathrm{KCD}-232$ on the Ch metabolism in rats fed a methioninesupplemented low casein (with threonine im-

Abbreviations: Ch, cholesterol; TG, triglyceride; PL, phospholipid; VLDL, very low density lipoproteins; LDL, low density lipoproteins; HDL, high density lipoproteins. 
balance) diet.

\section{MATERIALS AND METHODS}

Chemicals. $\quad\left[4-{ }^{14} \mathrm{C}\right]$ cholesterol $\quad(57 \mathrm{mCi} / \mathrm{mmol})$ and $\left[1 \alpha, 2 \alpha-{ }^{3} \mathrm{H}\right] \mathrm{Ch}(60 \mathrm{Ci} / \mathrm{mmol})$ were obtained from The Radiochemical Centre, and $\left[{ }^{3} \mathrm{H}\right]$ water $(100 \mathrm{mCi} / \mathrm{ml})$ from New England Nuclear. KCD-232 was synthesized in this laboratory. Other chemicals were of the best grade commercially available.

Animals and diets. Male Wistar rats (CLEA Japan Inc., Tokyo) were used throughout the experiments. They were maintained on a stock pellet (CE-2, CLEA Japan) in an air-conditioned room with a 6 a.m. to 6 p.m. light cycle until use. The animals were then divided into groups with equal body weights and fed the experimental diets. The composition of the basal diets expressed in percentage weight is shown in Table I. In the initial experiment shown in Fig. $1,0.3$ or $0.6 \%$ DL-methionine (Met) was added to the 10 or $20 \%$ casein diet at the expense of sucrose. In other experiments, to the $10 \%$ casein diet were added $0.4 \%$ Met, $0.4 \%$ Met plus $0.48 \%$ L-threonine (Thr), and $0.4 \%$ Met plus $0.3 \% \mathrm{KCD}-232$ at the expense of sucrose as shown in each table or figure. The feeding periods are also noted in each table and figure. Where indicated, KCD232 was suspended in $0.5 \%$ carboxymethyl cellulose and orally given to the animals by gastric intubation $(100 \mathrm{mg} /$ $5 \mathrm{ml} / \mathrm{kg}$ body weight) once a day during the experimental periods. Under these conditions, the rats in the druguntreated groups received carboxymethyl cellulose alone.

Lipid analyses. The rats were sacrificed by decapitation, and blood was collected in a glass tube and left to clot at room temperature. The liver was quickly removed, washed with cold $0.9 \% \mathrm{NaCl}$ solution, blotted on filter paper and weighed. The serum $(1 \mathrm{ml})$, obtained by centrifugation, and the liver $(0.5 \mathrm{~g})$ were homogenized with $20 \mathrm{vol}$. of chloroform-methanol $(2: 1, \mathrm{v} / \mathrm{v})$ and total lipids were

Table I. Composition of Experimental Diets ( $\%$ )

\begin{tabular}{lcc}
\hline \multicolumn{1}{c}{ Ingredient } & $10 \%$ Casein & $20 \%$ Casein \\
\hline Casein $^{a}$ & 10.0 & 20.0 \\
Sucrose $^{a}$ & 81.0 & 71.0 \\
& \multicolumn{2}{c}{1.0} \\
Corn oil $^{b}$ & & 5.0 \\
Mineral mixture $^{c}$ & & 1.0 \\
Vitamin mixture $^{c}$ & & 2.0 \\
Cellulose powder $^{a}$ & & \\
\hline
\end{tabular}

a Oriental Yeast Co., Ltd., Tokyo.

$b$ Yuro Yakuhin Co., Ltd., Tokyo.

c Mineral mixture 1 and vitamin mixture 1 arranged by Oriental Yeast Co., Ltd. were used. extracted according to the procedure of Folch et al. ${ }^{13)}$ After aliquots of the chloroform phase had been dried under nigrogen, $\mathrm{Ch}^{1{ }^{14)}} \mathrm{TG}^{15)}$ and $\mathrm{PL}^{16)}$ were determined by colorimetric methods. In the case of determining the liver $\mathrm{Ch}$ content, the extracted lipids (ca. $2 \mathrm{mg}$ ) were hydrolyzed with $3 \mathrm{ml}$ of $6 \%$ ethanolic $\mathrm{KOH}$ for $1 \mathrm{hr}$ at $45^{\circ} \mathrm{C}$. At the end of saponification, $3 \mathrm{ml}$ of distilled water was added and the sterols were extracted with $5 \mathrm{ml}$ of hexane. Aliquots of the hexane layer were evaporated to dryness and the Ch content was determined. ${ }^{14)}$

Lipoprotein separation and cholesterol determination. The serum lipoproteins were separated into HDL and VLDL + LDL fractions by a slightly modified version of the precipitation method described by Burstein et al. ${ }^{17)}$ and Lopes-Virella et al. ${ }^{18)}$ To $0.2 \mathrm{ml}$ of serum was added $2 \mathrm{ml}$ of a solution containing $0.02 \%$ sodium phosphotungstate and $50 \mathrm{~mm} \mathrm{MgCl}$. After standing for $20 \mathrm{~min}$, centrifugation was performed for $15 \mathrm{~min}$ at $800 \times g$. The precipitate was dissolved in $2 \mathrm{M} \mathrm{NaCl}$, diluted with distilled water and used for determining the $\mathrm{Ch}$ content of VLDL + LDL. The supernatant was used for the $\mathrm{Ch}$ determination of HDL. The total $\mathrm{Ch}$ contents of unfractionated whole serum (S-Ch), HDL (HDL-Ch) and $\mathrm{VLDL}+\mathrm{LDL}$ [(VLDL + LDL)-Ch] were determined by an enzymatic method using a Determiner TC " 555 " kit (Kyowa Hakko Kogyo Co., Ltd., Tokyo).

Determination of cholesterol absorption. Cholesterol absorption was measured by the dual-isotope ratio method described by Zilversmit and Hughes. ${ }^{19)}$ The intravenous dose of $\left[4-{ }^{14} \mathrm{C}\right] \mathrm{Ch}$ was prepared by dissolving in $25 \mu \mathrm{l}$ of $95 \%$ ethanol. Colloidal $\mathrm{Ch}$ was obtained by adding $0.5 \mathrm{ml}$ of $0.9 \% \mathrm{NaCl}$. The resulting mixture was injected intravenously within $1 \mathrm{hr}$ of its preparation, each rat receiving $0.762 \mu \mathrm{Ci}$ of $\left[{ }^{14} \mathrm{C}\right] \mathrm{Ch}$ per $0.5 \mathrm{ml}$. The oral dose of $\left[1 \alpha, 2 \alpha-{ }^{3} \mathrm{H}\right] \mathrm{Ch}$ was prepared as follows: $\left[{ }^{3} \mathrm{H}\right] \mathrm{Ch}(3.424 \mu \mathrm{Ci})$ was dissolved with $6 \mathrm{mg}$ of carrier $\mathrm{Ch}$ in $156 \mathrm{mg}$ of triolein (Tokyo Kasei Kogyo Co., Ltd., Tokyo), the oil phase of which was then suspended by sonication in water containing $7.5 \mathrm{mg}$ of sodium taurocholate (Sigma Chemical Co.) and the final volume was adjusted with water to $2 \mathrm{ml}$. Each rat therefore received $6 \mathrm{mg}$ of $\mathrm{Ch}$ plus $3.424 \mu \mathrm{Ci}$ of $\left[{ }^{3} \mathrm{H}\right] \mathrm{Ch}$ per $2 \mathrm{ml}$.

The intravenous isotope dose was injected into the tail vein of the rats. This was immediately followed by the oral isotope dose which was given by stomach tube to the rats which were all in the fed state. Three days after the doses, the animals were decapitated and blood was collected. To $0.8 \mathrm{ml}$ of serum was added $2 \mathrm{ml}$ of $15 \%$ ethanolic $\mathrm{KOH}$. The mixture was saponified at $85^{\circ} \mathrm{C}$ for $2 \mathrm{hr}$ and the nonsaponifiable fraction was extracted three times each with $4 \mathrm{ml}$ of petroleum ether into a counting vial. After the solvent had been dried, radioactivity was counted with a liquid scintillation spectrometer (Packard Tri-Carb model C2425) after adding $10 \mathrm{ml}$ of toluene scintillator. Cholesterol absorption was calculated with a ${ }^{3} \mathrm{H} /{ }^{14} \mathrm{C}$ ratio 
in the nonsaponifiable fraction and administration doses. $^{19)}$

Hepatic sterol and fatty acid syntheses in vivo using $\left[{ }^{3} \mathrm{H}\right]$ water. The rats were deprived of their diets at 9 a.m. on the 21 st day of feeding. $\left[{ }^{3} \mathrm{H}\right]$ water $(2 \mathrm{mCi} / 0.5 \mathrm{ml}$ isotonic $\mathrm{NaCl}$ solution/rat) was intraperitoneally injected 90 min prior to their sacrifice which was conducted by decapitation from $1: 30$ p.m. The animals were not given any further water during this $90 \mathrm{~min}$ period. Blood was collected in a glass tube and left to clot at room temperature. The liver was quickly removed, washed with cold $0.9 \% \mathrm{NaCl}$ solution, blotted on filter paper and weighed. The minced liver weighing about $1 \mathrm{~g}$ was placed in a screwcapped tube. After adding $1 \mathrm{ml}$ of wate and $2 \mathrm{ml}$ of $15 \%$ ethanolic $\mathrm{KOH}$, the mixture was saponified at $85^{\circ} \mathrm{C}$ for $5 \sim 6 \mathrm{hr}$ until totally dissolved. The nonsaponifiable lipids were then extracted three times each with $4 \mathrm{ml}$ of hexane. Carry-over $\left[{ }^{3} \mathrm{H}\right]$ water was eliminated by adding anhydrous sodium sulfate as a dehydrating agent to the pooled hexane and the mixture was filtered to remove the sodium sulfate. The filtrate was pooled in a glass tube, dried under nitrogen and dissolved in $1 \mathrm{ml}$ of acetone-ethanol $(1: 1$, $\mathrm{v} / \mathrm{v}$ ). Subsequently, the digitonin-precipitable sterols were fomerd, isolated and washed as described by $\mathrm{De}$ Matteis. ${ }^{20)}$ The digitonide was dissolved in $1 \mathrm{ml}$ of methanol, transferred quantitatively to a scintillation vial and counted after adding the toluene scintillator.

The residue remaining after the extraction of sterols was acidified to $\mathrm{pH} 2$ with concentrated $\mathrm{HCl}$ and the total fatty acids synthesized were extracted three times each with $4 \mathrm{ml}$ of petroleum ether. The pooled extracts were dried under nitrogen, dissolved in $2 \mathrm{ml}$ of chloroform and washed twice with water. The chloroform layer was quantitatively transferred to a scintillation vial, dried and counted as stated above.

Fifty $\mu$ l of serum was taken into a scintillation vial and its radioactivity counted after adding $10 \mathrm{ml}$ of Insta Gel (Packard Instrument Co., Inc.). The specific radioactivity of the serum water at the time each rat was killed was calculated by considering the water content of the serum to be $93 \%$, and the $\mu$ moles of water incorporated into the sterols $^{21)}$ and total fatty $\operatorname{acids}^{22)}$ was calculated by the specific radioactivity.

Statistical method. The statistical analysis was carried out using Student's $t$ test for paired data, and $p$ value of $<0.05$ was considered significant.

\section{RESULTS}

The initial study was attempted to examine the effect of a Met supplement to a $10 \%$ casein or $20 \%$ casein diet on the serum $\mathrm{Ch}$ level (Fig. 1). The serum $\mathrm{Ch}$ level was significantly increased by adding $0.3 \%$ Met to the $10 \%$ casein

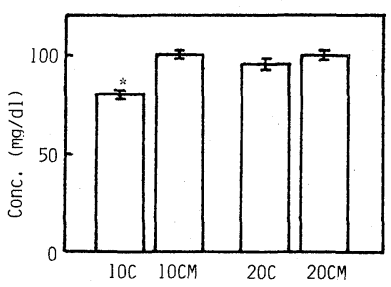

FIG. 1. Effect of the Methionine Supplement to Casein Diets on the Serum Cholesterol Levels of Rats.

Rats weighing $190 \mathrm{~g}$ in all groups were fed a $10 \%$ casein (10 C), $0.3 \%$ methionine-supplemented $10 \%$ casein $(10 \mathrm{CM}), 20 \%$ casein $(20 \mathrm{C})$ or $0.6 \%$ methioninesupplemented $20 \%$ casein $(20 \mathrm{CM})$ diet ad libitum. They were deprived of these diets at 9 a.m. on the 28 th day and decapitated from 1 p.m. Each value and vertical bar represent the mean of eight rats and the standard error, respectively. ${ }^{*} p<0.01$ to the $10 \mathrm{CM}$ group.

diet (groups 10C vs. 10CM), while the supplement of $0.6 \%$ Met to the $20 \%$ casein diet induced no further increase in the serum $\mathrm{Ch}$ level (groups 20C vs. 20CM). The $\mathrm{Ch}$ level of rats fed the $20 \%$ casein diet tended to be higher $(p<0.1)$ than that of rats fed the $10 \%$ casein diet (groups 10C vs. 20C). From these results, the enhancing effect of Met on the serum $\mathrm{Ch}$ level was verified in the case of the low casein diet. Hence the Met-supplemented low casein (with Thr imbalance) diet was subsequently used.

In the next experiment, the amount of Met supplemented to the $10 \%$ casein diet was increased from 0.3 to $0.4 \%$, and the feeding period was curtailed from 4 weeks to 2 weeks. Under these conditions, the effects of $\mathrm{Thr}$ as well as KCD-232 on the serum and liver lipids were estimated bacause of the fact that $\mathrm{Thr}$ could prevent fatty liver induced by feeding a low casein diet supplemented with a sulfurcontaining amino acid (cystine) in rats. ${ }^{9)}$ The results are shown in Table II. Despite the shortening of feeding period, the serum $\mathrm{Ch}$ level was significantly elevated by the supplement of $0.4 \%$ Met to the $10 \%$ casein diet (groups 1 vs. 2). Threonine failed to reduce the serum $\mathrm{Ch}$ level at a content of $0.48 \%$ (groups 2 vs. 3), whereas $\mathrm{KCD}-232$ significantly suppressed it at a content of $0.3 \%$ (groups $2 \mathrm{vs.}$. 4). No significant changes were observed in the 
Table II. Effects of Threonine AND KCD-232 on Hypercholesterolemia of Rats

INDUCED by a Methionine SupPLement to a Low CaSein Diet

\begin{tabular}{|c|c|c|c|c|c|c|c|c|c|c|}
\hline \multirow[b]{2}{*}{ Group } & \multirow[b]{2}{*}{ Treatment } & \multirow{2}{*}{$\begin{array}{l}\text { Initial } \\
\text { body wt } \\
\text { (g) }\end{array}$} & \multirow{2}{*}{$\begin{array}{l}\text { Final } \\
\text { body wt } \\
\text { (g) }\end{array}$} & \multirow{2}{*}{$\begin{array}{c}\text { Relative } \\
\text { liver wt } \\
(\mathrm{g} / 100 \mathrm{~g} \mathrm{bwt})\end{array}$} & \multicolumn{3}{|c|}{ Serum lipid levels } & \multicolumn{3}{|c|}{ Liver lipid levels } \\
\hline & & & & & $\mathrm{Ch}$ & $\begin{array}{c}\text { TG } \\
(\mathrm{mg} / \mathrm{dl} \text { serum) }\end{array}$ & PL & $\mathrm{Ch}$ & $\begin{array}{c}\text { TG } \\
(\mathrm{mg} / \mathrm{g} \text { wet liver })\end{array}$ & PL \\
\hline 1 & $10 \%$ casein $(C)$ & $241 \pm 6$ & $267 \pm 7$ & $3.15 \pm 0.05$ & $87 \pm 6^{a}$ & $125 \pm 12$ & $154 \pm 8$ & $2.0 \pm 0.1$ & $12.0 \pm 1.5$ & $32.2 \pm 0.6$ \\
\hline 2 & $\mathrm{C}+0.4 \%$ Met $(\mathrm{CM})$ & $240 \pm 6$ & $274 \pm 7$ & $3.07 \pm 0.05$ & $102 \pm 3$ & $102 \pm 14$ & $160 \pm 8$ & $2.3 \pm 0.3$ & $21.5 \pm 4.2$ & $30.3 \pm 1.7$ \\
\hline 3 & $\mathrm{CM}+0.48 \% \mathrm{Thr}(\mathrm{CMT})$ & $240 \pm 6$ & $281 \pm 7$ & $3.38 \pm 0.31$ & $104 \pm 4$ & $115 \pm 22$ & $168 \pm 7$ & $2.1 \pm 0.1$ & $16.8 \pm 3.2$ & $29.6 \pm 0.3$ \\
\hline 4 & $\mathrm{CM}+0.3 \% \mathrm{KCD}-232(\mathrm{CMK})$ & $240 \pm 6$ & $281 \pm 7$ & $3.16 \pm 0.05$ & $67 \pm 4^{b}$ & $65 \pm 10^{a}$ & $100 \pm 6^{b}$ & $2.0 \pm 0.1$ & $5.9 \pm 0.9^{a}$ & $37.4 \pm 1.5^{a}$ \\
\hline
\end{tabular}

Rats were fed experimental diets for 14 days ad libitum. On the 14th day, the animals were deprived of their diets at 9 a.m. but allowed free access to water until sacrifice which was performed by decapitation from 1 p.m. Each value represents the mean of six rats \pm S.E.M. ${ }^{a} p<0.05$ and ${ }^{b} p<0.001$ to Group 2 , respectively.

Table III. Cholesterol Absorption in Rats Fed a Methionine-supplemented Low CASEIN Diet AND THE EFFECT OF KCD-232

\begin{tabular}{|c|c|c|c|c|c|c|c|c|c|}
\hline \multirow[b]{2}{*}{ Group } & \multirow[b]{2}{*}{ Treatment } & \multirow{2}{*}{$\begin{array}{l}\text { Initial } \\
\text { body wt } \\
\text { (g) }\end{array}$} & \multirow{2}{*}{$\begin{array}{l}\text { Final } \\
\text { body wt } \\
\text { (g) }\end{array}$} & \multirow{2}{*}{$\begin{array}{c}\text { Relative } \\
\text { liver wt } \\
(\mathrm{g} / 100 \mathrm{~g} \mathrm{bwt})\end{array}$} & \multicolumn{2}{|c|}{ Cholesterol levels } & \multirow{2}{*}{$\begin{array}{c}\text { Serum } \\
{ }^{3} \mathrm{H}-\mathrm{Ch}(\mathrm{PO}) \\
(\mathrm{dpm} / \mathrm{ml})\end{array}$} & \multirow{2}{*}{$\begin{array}{c}\text { Serum } \\
{ }^{14} \mathrm{C}-\mathrm{Ch}(\mathrm{IV}) \\
(\mathrm{dpm} / \mathrm{ml})\end{array}$} & \multirow{2}{*}{$\begin{array}{c}\text { Absorbed } \\
\text { cholesterol } \\
(\%)\end{array}$} \\
\hline & & & & & $\begin{array}{c}\text { Serum } \\
(\mathrm{mg} / \mathrm{dl})\end{array}$ & $\begin{array}{l}\text { Liver } \\
(\mathrm{mg} / \mathrm{g})\end{array}$ & & & \\
\hline 1 & $10 \%$ Casein $(\mathrm{C})_{2} \& \mathrm{CMC}$ & $295 \pm 9$ & $302 \pm 11$ & $3.71 \pm 0.24$ & $109 \pm 3^{b}$ & $2.9 \pm 0.3$ & $14591 \pm 834^{a}$ & $8396 \pm 379^{a}$ & $38.8 \pm 2.3$ \\
\hline 2 & $\mathrm{C}+0.4 \% \operatorname{Met}(\mathrm{CM}) \& \mathrm{CMC}$ & $299 \pm 5$ & $310 \pm 10$ & $3.75 \pm 0.10$ & $144 \pm 9$ & $2.7 \pm 0.1$ & $18185 \pm 1160$ & $11079 \pm 847$ & $37.0 \pm 3.2$ \\
\hline 3 & CM \& KCD-232 (100 mg/kg/day $)$ & $298 \pm 5$ & $319 \pm 8$ & $3.99 \pm 0.14$ & $61 \pm 7^{c}$ & $2.5 \pm 0.1$ & $7582 \pm 380^{c}$ & $4393 \pm 429^{c}$ & $39.0 \pm 2.0$ \\
\hline
\end{tabular}

Rats were fed experimental diets for 17 days ad libitum. On the 14 th day, $0.762 \mu \mathrm{Ci}$ of $\left[4-{ }^{14} \mathrm{C}\right]$ cholesterol was injected into the tail vein followed immediately by $3.424 \mu \mathrm{Ci}$ of $\left[1 \alpha, 2 \alpha{ }_{-}^{3} \mathrm{H}\right]$ cholesterol dose which was given by stomach tube. The experimental diets were then resumed ad libitum. The final administration of carboxymethyl cellulose (CMC) or KCD-232 was orally performed at 9 a.m. on the 17 th day. The rats were allowed free access to the diets and water until sacrifice which was conducted by decapitation from 1 p.m. Each value represents the mean of four rats \pm S.E.M. ${ }^{a} p<0.05,{ }^{b} p<0.01$ and ${ }^{c} p<0.001$ to Group 2, respectively. 

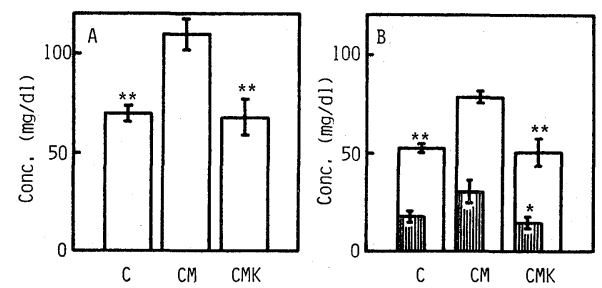

FIG. 2. Cholesterol Distribution in Serum Lipoproteins of Rats Fed a Methionine-supplemented Low Casein Diet and the Effect of KCD-232.

Rats were given a $10 \%$ casein (C) diet, C diet supplemented with $0.4 \%$ methionine (CM) or CM diet with oral administration of KCD-232 at a dose of $100 \mathrm{mg} / \mathrm{kg}$ of body weight once a day (CMK) for 14 days. The final oral administration of KCD-232 was performed at 9 a.m., at which time the animals were deprived of their diets but allowed free access to water until sacrifice. They were decapitated from 1 p.m. The initial body weights of the C, $\mathrm{CM}$ and $\mathrm{CMK}$ groups were $217 \pm 7,216 \pm 8$ and $218 \pm 7 \mathrm{~g}$ (the mean of six rats \pm S.E.M.), respectively. A, total cholesterol content of unfractionated whole serum (S-Ch). B, HDL-Ch $(\square)$ and (VLDL + LDL)-Ch (mाtाm). Each value and vertical bar represent the mean of six rats and the standard error, respectively. ${ }^{*} p<0.05$ and ${ }^{* *} p<0.01$ to the CM group.

serum TG and PL levels by the Met supplement. Threonine had no significant effects on the serum TG and PL levels but KCD-232 significantly decreased both lipid levels. The liver TG content showed a tendency $(p<0.1)$ to be increased by the Met supplement. Threonine slightly prevented, although not significantly, this tendency to increase, and KCD-232 strongly reduced it. The liver PL content was not changed by the Met supplement and Thr had no further effect on it, while KCD-232 significantly increased it. The liver $\mathrm{Ch}$ contents were almost constant among the four groups. The growth of the rats and their relative liver weight were not affected by Met, Thr and KCD-232. As illustrated in Fig. 2, to estimate the $\mathrm{Ch}$ distribution among serum lipoproteins in the rats, the lipoproteins were separated into HDL and VLDL + LDL fractions by the precipitation method and the $\mathrm{Ch}$ content of each fraction was determined. The total $\mathrm{Ch}$ content of unfractionated whole serum (S-Ch) of the rats fed the Metsupplemented $10 \%$ casein $(\mathrm{CM})$ diet signifi-

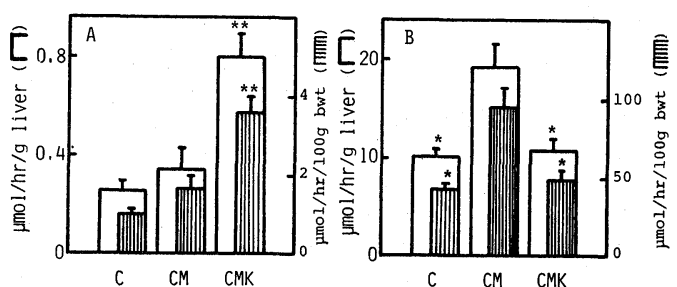

FIG. 3. Synthetic Rates of Hepatic Sterols and Fatty Acids in Rats Fed a Methionine-supplemented Low Casein Diet and the Effect of KCD-232.

Rats weighing $204 \mathrm{~g}$ in all groups were fed a $10 \%$ casein (C) diet, $\mathrm{C}$ diet supplemented with $0.4 \%$ methionine (CM) or CM diet supplemented with $0.3 \% \mathrm{KCD}-232$ (CMK) ad libitum and deprived of their diets at 9 a.m. on the $21 \mathrm{st}$ day. $\left[{ }^{3} \mathrm{H}\right]$ Water $(2 \mathrm{mCi} / \mathrm{rat})$ was intraperitoneally injected $90 \mathrm{~min}$ prior to sacrifice which was conducted by decapitation from $1: 30$ p.m. The animals were not given any further water during this period of $90 \mathrm{~min}$. The $\left[{ }^{3} \mathrm{H}\right]$ water incorporation into hepatic digitonin-precipitable sterols (A) and total fatty acids (B) was determined as described in Materials AND Methods. Each value and vertical bar represent the mean of six rats and the standard error. ${ }^{*} p<0.05$ and ${ }^{* *} p<0.01$ to the CM group.

cantly increased by $57 \%$ in comparison with that of the rats fed the $10 \%$ casein (C) diet. This rise was due to an increase in both HDL-Ch and (VLDL + LDL)-Ch by 49 and $67 \%$, respectively, although the latter was an increasing tendency $(p<0.1)$ KCD-232 significantly reduced the $\mathrm{S}-\mathrm{Ch}$ level of $\mathrm{CM}$ rats by significantly decreasing both HDL-Ch and (VLDL + LDL)-Ch (CM vs. CMK).

The next group of studies was conducted to deduce the possible mechanism(s) involved in the amino acid imbalance-induced hypercholesterolemia and the action of KCD-232 on it. Table III shows $\mathrm{Ch}$ absorption from the intestine evaluated by a dual-isotope serum ratio method. ${ }^{19)}$ Neither an enhancement in $\mathrm{Ch}$ absorption in rats fed the imbalance diet (groups 1 vs. 2) nor a reduction in rats treated with KCD-232 (groups 2 vs. 3) was observed. However, the radioactivities in the serum of ${ }^{3} \mathrm{H}$ derived from an oral dose of $\left[1 \alpha, 2 \alpha-{ }^{3} \mathrm{H}\right] \mathrm{Ch}$ and ${ }^{14} \mathrm{C}$ derived from an intravenous dose of $\left[4-{ }^{14} \mathrm{C}\right] \mathrm{Ch}$ significantly stagnated in the imbalance diet-fed rats (groups 1 vs. 2) and significantly diminished in the drug-treated rats (groups 2 vs. 3). Figure 3 shows the 
synthetic rates of hepatic sterols and fatty acids in vivo. $\left[{ }^{3} \mathrm{H}\right]$ water was used for measuring the sterol and fatty acid synthetic rates, since the incorporation of ${ }^{3} \mathrm{H}$ from $\left[{ }^{3} \mathrm{H}\right]$ water has been reported to provide reliable estimates for the absolute rates of sterol $^{21)}$ and fatty acid ${ }^{22}$ ) syntheses in vivo. The results are expressed as both $\mu$ moles of $\mathrm{H}_{2} \mathrm{O}$ incorporated $/ \mathrm{hr} / \mathrm{g}$ of wet liver and $\mu$ moles of $\mathrm{H}_{2} \mathrm{O}$ incorporated $/ \mathrm{hr} /$ whole liver $/ 100 \mathrm{~g}$ of body weight. The supplement of Met to the low casein diet had no significant effect on the sterol synthetic rate $(\mathrm{C}$ vs. $\mathrm{CM}$ ), while the drug addition to the $\mathrm{CM}$ diet showed a marked increase in it (CM vs. CMK). On the other hand, the fatty acid synthetic rate was highly enhanced by the Met supplement (C vs. CM) and KCD-232 significntly reduced it (CM vs. CMK). The serum $\mathrm{Ch}$ levels of the $\mathrm{C}, \mathrm{CM}$ and $\mathrm{CMK}$ groups were $90 \pm 6,114 \pm 7$ and $80 \pm 7 \mathrm{mg} / \mathrm{dl}$ of serum (the mean of six rats \pm SEM, $p<0.05$ for $\mathrm{C} v s$. CM and $p<0.01$ for $\mathrm{CM}$ vs. $\mathrm{CMK}$ ), respectively. The liver TG levels of the $\mathrm{C}, \mathrm{CM}$ and $C M K$ groups were $17.2 \pm 1.7,49.3 \pm 12.1$ and $5.5 \pm 0.8 \mathrm{mg} / \mathrm{g}$ of liver (the mean of six rats $\pm \mathrm{SEM}, p<0.05$ for $\mathrm{C} v s$. CM and $\mathrm{CM} v s$. CMK).

\section{DISCUSSION}

The initial study showed that increasing dietary casein tended to increase the serum $\mathrm{Ch}$ levels of rats (Fig. 1). This result is in good agreement with the study of Terpstra et al. ${ }^{4)}$ who found a gradual increase in serum $\mathrm{Ch}$ concentrations of rabbits receiving 10, 20 and $40 \%$ casein diets. The supplement of Met to the $10 \%$ casein diet caused a further increase in the serum $\mathrm{Ch}$ of rats, whereas that of Met to the $20 \%$ casen diet showed no further increase in serum $\mathrm{Ch}$ (Fig. 1). The latter finding is similar to that of Hamilton and $\mathrm{Carroll}^{23)}$ who have reported that a Met supplement to a $27 \%$ casein diet low in fat failed to induce any further increase in the serum $\mathrm{Ch}$ concentrations of rabbits. The former finding shows that an amino acid imbalance diet (with $\mathrm{Thr}$ imbalance) induces endogenous hypercholes- terolemia, in addition to fatty liver ${ }^{9,24)}$ in rats. Fatty liver induced by such an amino acid imbalance is known to be prevented by Thr. ${ }^{9}$ ) Threonine, however, failed to reduce the hypercholesterolemia developed by the imbalance diet low in fat at a dietary content of $0.48 \%$ and showed little effect on accumulated liver TG (Table II). The reason for the failure of $\mathrm{Thr}$ is not clear at present, but it may be related to the low content of dietary fat $(1 \%$ corn oil) and/or an inadequate amount of $\mathrm{Thr}$ supplement. The elevation in serum $\mathrm{Ch}$ of the imbalance diet-fed rats is shown to be due to those in both HDL-Ch and (VLDL+LDL)$\mathrm{Ch}$ (Fig. 2). KCD-232 reduced the serum $\mathrm{Ch}$ level of the imbalance diet-fed rats by decreasing both HDL-Ch and (VLDL+LDL)-Ch.

It seems unlikely that the elevation in the serum $\mathrm{Ch}$ of the imbalance diet-fed rats is due to either an enhanced $\mathrm{Ch}$ absorption from the intestine or an enhanced $\mathrm{Ch}$ synthesis in the liver. The drug also had neither a suppressive effect on $\mathrm{Ch}$ absorption nor an inhibitory effect on hepatic Ch synthesis (Table III, Fig. 3). Hepatic sterol synthesis, far from decreasing, is increased by KCD-232 treatment despite its ability to inhibit sterol synthesis due to a KCD-232 metabolite, 4-(4'-chlorobenzyloxy)benzoic acid. ${ }^{25}$ On the contrary, radioactivities in the serum of ${ }^{3} \mathrm{H}$ derived from an oral dose of $\left[{ }^{3} \mathrm{H}\right] \mathrm{Ch}$, and ${ }^{14} \mathrm{C}$ derived from an intravenous dose of $\left[{ }^{14} \mathrm{C}\right] \mathrm{Ch}$ were significantly higher in rats fed the Met-supplemented $10 \%$ casein diet than those fed the $10 \%$ casein diet. Conversely, KCD-232 decreased the radioactivities of $\left[{ }^{3} \mathrm{H}\right] \mathrm{Ch}$ and $\left[{ }^{14} \mathrm{C}\right] \mathrm{Ch}$ present in the serum. The serum $\mathrm{Ch}$ is excreted partly as sterols and partly as bile acids; in rats, the conversion of $\mathrm{Ch}$ to bile acids is much the more important of these two pathways. ${ }^{26)}$ It is therefore suggested that the Ch clearance from the circulation, which may have been impaired in the imbalance diet-fed rats, was enhanced in the KCD-232-treated, imbalance diet-fed rats, presumably by enhancing the bile acid formation in the liver.

Fatty liver induced in rats fed the Metsupplemented $10 \%$ casein diet was reduced by 
KCD-232 treatment. Hepatic lipogenesis, above all the synthesis of $\mathrm{TG}$, from $\left[{ }^{14} \mathrm{C}\right]$ acetate has been reported to increase in liver slices of rats fed a Met-supplemented low casein diet. ${ }^{24)}$ The current study, which shows a significant increase in the in vivo synthesis of hepatic fatty acid in rats fed the Metsupplemented $10 \%$ casein diet (Fig. 3), is consistent with the previous work. ${ }^{24)}$ The amino acid imbalance-induced enhancement in hepatic fatty acid synthesis was prevented by KCD-232. This drug has been reported to inhibit hepatic fatty acid synthesis in rats which is attributable to its metabolite $4-\left(4^{\prime}\right.$ chlorobenzyloxy)benzoyl-coenzyme $\left.\mathrm{A},{ }^{25}\right)$ like natural fatty acyl-coenzyme $\mathrm{A}$ thioesters. ${ }^{27,28)}$ $\mathrm{KCD}-232$ is therefore considered to reduce both the serum TG and development of the amino acid imbalance-induced fatty liver by inhibiting TG synthesis via a suppression of the enhanced fatty acid synthesis in the liver. KCD-232 often reduced the serum $\mathrm{Ch}$ level of the Met-supplemented $10 \%$ casein diet-fed rats below that of the $10 \%$ casein diet-fed rats (Tables II and III). The hypotriglyceridemic activity of KCD-232 may partly explain this phenomenon; the $\mathrm{Ch}$ moiety as well as TG moiety of serum lipoproteins can be reduced by the strong hypotriglyceridemic activity. Further studies are needed to clarify this aspect.

\section{REFERENCES}

1) K. K. Carroll and R. M. G. Hamilton, J. Food Sci., 40, 18 (1975).

2) D. Kritchevsky, S. A. Tepper, D. E. Williams and J. A. Story, Atherosclerosis, 26, 397 (1977).

3) A. C. Ross, C. R. Minik and D. B. Zilversmit, Atherosclerosis, 29, 301 (1978).

4) A. H. M. Terpstra, L. Harkes and F. H. van der Veen, Lipids, 16, 114 (1981).
5) P. Hevia, F. W. Kari, E. A. Ulman and W. J. Visek, J. Nutr., 110, 1224 (1980).

6) C. R. Sirtori, E. Agradi, F. Conti, O. Mantero and E. Gatti, Lancet, I, 275 (1977).

7) N. R. Yadav and I. E. Liener, Nutr. Rep. Int., 16, 385 (1977).

8) K. Yagasaki, H. Tanaka, M. Yamaguchi and M. Kametaka, Nippon Nôgeikagaku Kaishi, 49, 387 (1975).

9) A. Yoshida and A. E. Harper, J. Biol. Chem., 235, 2586 (1960).

10) G. Bazzano, J. A. D'Elia and R. E. Olson, Science, 169, 1208 (1970).

11) J. K. Solomon and R. L. Geison, J. Nutr., 108, 936 (1978).

12) K. Yagasaki, K. Okada, K. Takagi and T. Irikura, Proc. Jpn. Conf. Biochem. Lipids, 24, 377 (1982).

13) J. Folch, M. Lees and G. H. Sloane Stanley, J. Biol. Chem., 226, 497 (1957).

14) B. Zak, Am. J. Clin. Path., 27, 583 (1957).

15) E. Van Handel, Clin. Chem., 7, 249 (1961).

16) P. S. Chen, Jr., T. Y. Toribara and H. Warner, Anal. Chem., 28, 1756 (1956).

17) M. Burstein, H. R. Scholnick and R. Morfin, J. Lipid Res., 11, 583 (1970).

18) M. F. L. Lopes-Virella, P. G. Stone and J. A. Colwell, Diabetologia, 13, 285 (1977).

19) D. B. Zilversmit and L. B. Hughes, J. Lipid Res., 15, 465 (1974).

20) F. De Matteis, Biochem. J., 109, 775 (1968).

21) D. J. Jeske and J. M. Dietschy, J. Lipid Res., 21, 364 (1980).

22) T. Sakurai, S. Miyazawa, Y. Shindo and T. Hashimoto, Biochim. Biophys. Acta, 360, 275 (1974).

23) R. M. G. Hamilton and K. K. Carroll, Athersclerosis, 24, 47 (1976).

24) M. Ogura, Agric. Biol. Chem., 36, 1159 (1972).

25) K. Yagasaki, K. Okada, T. Mochizuki, K. Takagi and T. Irikura, Proc. Jpn. Conf. Biochem. Lipids, 23, 362 (1981).

26) M. D. Siperstein, M. E. Jayko, I. L. Chaikoff and W. G. Dauben, Proc. Soc. Exp. Biol. Med., 81, 720 (1952).

27) S. Numa, E. Ringelmann and F. Lynen, Biochem. Z., 343, 243 (1965).

28) H. Knoche, T. W. Esders, K. Koths and K. Bloch, J. Biol. Chem., 248, 2317 (1973). 